\section{Om propaganda, terror og interessekonflikter}

Per Arne Norum etterlyser i Tidsskriftet nr. 5/2008 større objektivitet i dekningen av voldelige internasjonale konflikter (1). Han anklager også Tidsskriftets redaksjon for ensidighet og manglende troverdighet i forbindelse med reportasjen fra Gaza.

Hans bekymring for objektiviteten blir noe parodisk når hans ærend tydeligvis er å forsvare Israels massive angrep på Gaza. Norum påstår at forsvarerne er ansvarlige når sivile blir drept $\mathrm{i}$ deres egen by.

Tillat meg en ytring fra en som selv har opplevd noe liknende (ikke i Gaza): Når en overlegen teknologisk krigsmakt bomber og beskyter en vanlig tettbebodd by med raketter og tungt artilleri, er det nesten bare sivile som blir rammet. De militære sitter i bunkere og har underjordiske ganger. Skal man overvinne dem, må angriperen gå inn med bakkestyrker fra hus til hus, fra kjeller til kjeller. Det koster store tap av egne styrker. Det enkleste er da å bombe og beskyte sivilbefolkningen, som ikke har noen muligheter til å søke dekning. Denne form for krigføring kalles terror og er en krigsforbrytelse - uansett hvem som utfører den, uansett om ens sympati på forhånd ligger hos angriperen eller forsvareren.

Tidsskriftets redaksjon kan antakelig rolig overse anklagene om ensidighet i Gaza-reportasjen - de tar jo også inn Norums propaganda fra den andre siden.

\section{Ragnar Stien}

Oslo

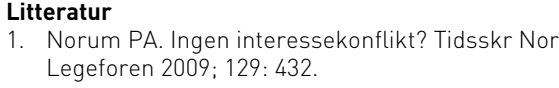

\section{Fra undring til uro - Tidsskriftet, nobelprisen og HPV-vaksinen}

Alle potensielle nyvinninger, særlig intervensjoner overfor friske mennesker, må gjennomgå kritisk vurdering av nytte, sikkerhet og kostnad. Tidsskriftets redaktør har følt ansvar overfor HPV-vaksinen. Vår undring er at dette har medført fire kritiske norske og én internasjonal lederartikkel som konkluderer med at dokumentasjonen av nytte er utilstrekkelig og at implementeringen bør utsettes - stikk i strid med anbefalingene fra fagmiljøene $i$ de fleste land og fra sentrale redaktører. I en lederartikkel i The Lancet oppfordres det faktisk til å gjøre vaksinasjonen obligatorisk for jenter i 11-12-årsalderen i alle EU-land.

Nobelprisen i medisin for 2008 ble delt mellom Harald zur Hausen for hans grunnleggende forskning om humant papillomvirus (HPV) og oppdagerne av hiv. Disse arbeidene har vært helt avgjørende for for- ståelsen av to av verdens mest utbredte infeksjonssykdommer. I lys av Tidsskriftets sterke og kritiske engasjement om HPVvaksinen var vi spente på hvilken omtale årets nobelpris ville få. Vi må konstatere at fokus og omtale i Tidsskriftet nr. 23/2008 kun knyttet seg til om det var riktig antall og rette personer som fikk «hivprisen» (1). Tradisjonen med å redegjøre for den avgjørende forskningen, de sentrale artiklene og den kliniske betydningen, ispedd litt bibliografisk om vinnerne, ble ikke fulgt opp. Vi vil tro at nettopp dette er sentralt for Tidsskriftets lesere. Denne gangen var lederen kun knyttet til rettferdigheten vedrørende «hivprisen» og Nobelkomiteens antatte indre politiske vurderinger. Verken HPV eller zur Hausen er nevnt. På bakgrunn av redaktørens sterke HPV-engasjement var det øredøvende taust. Passet årets pris dårlig med «den redaksjonelle profil» slik at det like greit ble forbigått i stillhet?

Vi ønsker ikke å diskutere for og imot vaksinasjonen, men et nyttepoeng har vært lite påaktet og fortjener å trekkes frem: Potensialet til å redusere mortalitet og morbiditet ved prematuritet etter konisering. For tidlig fødsel er den viktigste årsak til spedbarnsdødelighet i Norge og globalt. De økonomiske kostnadene ved død er lave, men ved livslang morbiditet kan kostnadene bli enorme. Disse er ikke tatt med i Kunnskapssenterets kostnad-nytte-vurdering. Tre nye viktige og relevante norske studier har vakt internasjonal oppmerksomhet (2-4). Mors gjennomsnittsalder ved første fødsel $ø$ øer, det betyr at en økende andel av koniseringene finner sted forut for fødslene. HPV-vaksinasjon antas å kunne føre til halvert antall behandlingstrengende forstadier (CIN 2+). I Norge koniseres vel 3000 kvinner årlig. Dette betyr at for hver oppstått cervixcancer koniseres ti kvinner, som deretter vil ha økt risiko for prematur fødsel! Risikoen for fødsel før 28. svangerskapsuke eller for å få barn under $1000 \mathrm{~g} \mathrm{er}$ spesielt stor. Behandling og oppfølging av disse barna er en stor belastning økonomisk og sosialt - for både samfunnet og familien. Dette kan hindres ved HPV-vaksinasjon.

\section{Claes Tropé}

Oslo

\section{Ole-Erik Iversen}

Bergen

\section{Litteratur}

1. Haug C. Høyt henger de... Tidsskr Nor Legeforen 2008; 128: 2689

2. Moster D, Lie RT, Markestad T. Long-term medical and social consequences of preterm birth. N Eng J Med 2008; 359: 262-73.

3. Albrechtsen $\mathrm{S}$, Rasmussen $\mathrm{S}$, Thoresen $\mathrm{S}$ et al. Pregnancy outcome in women before and after cervical conization. BMJ 2008; 337: a1343

4. Sjøborg KD, Vistad I, Myhr SS et al. Pregnancy outcome after cervical cone excision: a case-control study. Acta Obstet Gynecol Scand 2007; 86: 423-8.

\section{Redaktøren svarer:}

Jeg er enig med Tropé \& Iversen i at dersom kostnad-nytte-vurderinger skal kunne brukes til noe fornuftig, må de være basert på realistiske og tilstrekkelig komplekse modeller av sykdomsforløp og utfall. Den største svakheten ved de publiserte vurderingene av HPV-vaksinen er at de har vært basert på altfor enkle modeller $(1,2)$. Jeg er derfor enig $i$ at nytteeffekten av vaksinen når det gjelder premature fødsler etter koniseringer burde inkluderes i modellene.

Tropé \& Iversen bemerker at jeg valgte å omtale nobelprisen i fysiologi eller medisin på en annen måte enn det har vært gjort tidligere. Det er riktig. Poenget var nettopp at den tradisjonelle hyllest til enkeltpersoner sjelden er relevant for viktige medisinske fremskritt. Jeg brukte oppdagelsen av hiv som eksempel, og jeg kan avkrefte at det var av «politiske» grunner at jeg ikke omtalte HPV-forskningen på samme måte. Samtidig kan jeg forstå hvorfor spørsmålet stilles, gitt min interesse for HPV-vaksinen.

Harald zur Hausen fikk nobelprisen for sitt arbeid for å få gjennomslag for at humant papillomvirus var årsak til livmorhalskreft. Det tok tid fordi den rådende oppfatning innen fagmiljøene var at livmorhalskreft var forårsaket av et herpesvirus (3). Men, som kjent, det er sjelden den kompakte majoritet driver vitenskapen fremover.

Hans oppdagelse er selvsagt utgangspunktet for at det var mulig å begynne å forske på en vaksine. Men det er oppdagelsen av sammenhengen mellom virus og kreft, ikke vaksinen, som var årsaken til at han fikk prisen. Nobelförsamlingen avslutter sin begrunnelse for å gi prisen til zur Hausen med å understreke at det er betydelig usikkerhet knyttet til effekten av vaksinen (4): «However, discoveries whether these vaccines are effective in preventing not only against cervical lesions but also cervical cancer and death must await the collection of epidemiological data during the coming decades. In addition, the duration of the vaccine's protection is unclear: do they provide life-long immunity or will booster doses be needed? Since the vaccines aim to protect against the two virus strains that cause $70 \%$ of the cervical cancers, will other strains emerge as a major cause of the tumours?»

\section{Charlotte Haug}

Tidsskriftet

\footnotetext{
Litteratur

1. Haug C. HPV-vaksiner - effekt, sikkerhet og kostnadseffektivitet. Tilsvar. Tidsskr Nor Lægeforen 2007; 127: 1674

2. Haug CJ. Human papillomavirus vaccination - reasons for caution. N Engl J Med 2008; 359: 861-2.

3. Rawls WE, TompkinsWAF, Melnick JL. The association of herpesvirus type 2 and carcinoma of the uterine cervix. Am J Epidemiol 1969; 89: 547-54.

4. Nobelförsamlingen. The Nobel Prize in Physiology or Medicine 2008. Advanced information. http:// nobelprize.org/nobel_prizes/medicine/laureates/ 2008/adv.html (10.3.2009)
} 